\section{En høygravid kvinne med hodepine og feber}

NOE Å LAERE AV

\section{INGVIL K. SØRBYE}

E-post: isorbye@ous-hf.no

Fødeavdelingen

Oslo universitetssykehus, Rikshospitalet

og

Nasjonalt kompetansetjeneste for kvinnehelse

Oslo universitetssykehus, Rikshospitalet

Ingvil K. Sørbye (f. 1968) er spesialist i fødselshjelp og kvinnesykdommer og overlege.

Forfatter har fylt ut ICMJE-skjemaet og oppgir ingen interessekonflikter.

\section{HILDE B. ANDERSEN}

Medisinsk avdeling

Sykehuset Østfold

Hilde B. Andersen (f. 1978) er lege i spesialisering.

Forfatter har fylt ut ICMJE-skjemaet og oppgir ingen interessekonflikter.

\section{ERIK MELIN}

Avdeling for bildediagnostikk

Sykehuset Østfold

Erik Melin (f. 1978) er spesialist i radiologi og i nevroradiologi (svensk grenspesialitet) og overlege. Forfatter har fylt ut ICMJE-skjemaet og oppgir ingen interessekonflikter.

\section{INGVILD NORD ØY}

Seksjon for klinisk immunologi og infeksjonssykdommer

Oslo universitetssykehus, Rikshospitalet

og

Institutt for indremedisinsk forskning

Oslo universitetssykehus, Rikshospitalet

Ingvild Nordøy (f. 1960) er spesialist i infeksjonssykdommer og overlege.

Forfatter har fylt ut ICMJE-skjemaet og oppgir følgende interessekonflikter: Hun har fått foredragshonorar fra CSL Behring og er medlem av Gileades rådgivningsgruppe.

En gravid kvinne fikk i tredje trimester hodepine, svimmelhet og tungpustenhet. Mange friske gravide opplever slike symptomer i moderat grad i løpet av et svangerskap. Men i dette tilfellet skulle symptomene vise seg å skyldes alvorlig, livstruende sykdom.

En kvinne i 3o-årene, opprinnelig fra et afrikansk land, var gravid med sitt syvende barn da hun i svangerskapsuke 32 ble innlagt i sykehus grunnet hodepine, svimmelhet og tungpustenhet. Hun hadde tidligere alltid vært frisk, hadde bodd i Norge i over ti år og snakket noe norsk. Hennes tidligere svangerskap og fødsler hadde vært upåfallende, med 
unntak av svangerskapsdiabetes i det forrige, to år tidligere.

I det aktuelle svangerskapet hadde hun fulgt ordinære kontroller hos sin fastlege.

Blodprøver tatt tidlig i svangerskapet var negative for hiv, viral hepatitt og syfilis og viste gjennomgått Toxoplasma-infeksjon. I annet trimester fikk hun påvist kostregulerbar svangerskapsdiabetes, men ønsket ikke oppfølging på diabetespoliklinikk og ble derfor fulgt opp av fastlegen. Hun var noe overvektig - vekten var $92 \mathrm{~kg}$ i siste del av svangerskapet. Ved innleggelsen oppga hun at hun var plaget av tørrhoste og tungpustenhet, i tillegg til akutt innsettende hodepine, svimmelhet og dobbeltsyn. Hun hadde normalt blodtrykk, var afebril og hadde ingen nevrologiske utfall ved undersøkelse. Blodprøver viste et CRP-nivå på $65 \mathrm{mg} / \mathrm{l}$ (normalt $<4 \mathrm{mg} / \mathrm{l}$ ) og normale leukocytter. CT caput ble vurdert som normalt. Røntgen thorax ble ikke tatt, da hodepinen ble presentert som hovedproblemet. Kvinnen reiste hjem påfølgende dag, i god form.

Uken etter, i svangerskapsuke 33, tok hun kontakt med fastlegen etter symptomer som vekslende feber og frysninger. Hun fikk råd om å bruke paracetamol til symptomlindring. I to uker hadde hun så vekslende feber, svimmelhet og hodepine, etter hvert daglig oppkast, vedvarende tørrhoste og tung pust. Hun ble på nytt henvist til medisinsk avdeling ved lokalsykehuset. Ved innkomst ( $\operatorname{dag} 1$ ) var hun febril med temperatur $38,0^{\circ} \mathrm{C}$, blodtrykk $144 / 77 \mathrm{~mm} \mathrm{Hg}$, puls 101/min, respirasjonsfrekvens 16/min og $\mathrm{O}_{2}$-metning $98 \%$. CRP-nivået hadde steget til $130 \mathrm{mg} / \mathrm{l}$. Røntgen thorax ved innleggelsen viste diffuse lungefortetninger bilateralt, oppfattet som mulig atypisk pneumoni (fig 1 ).

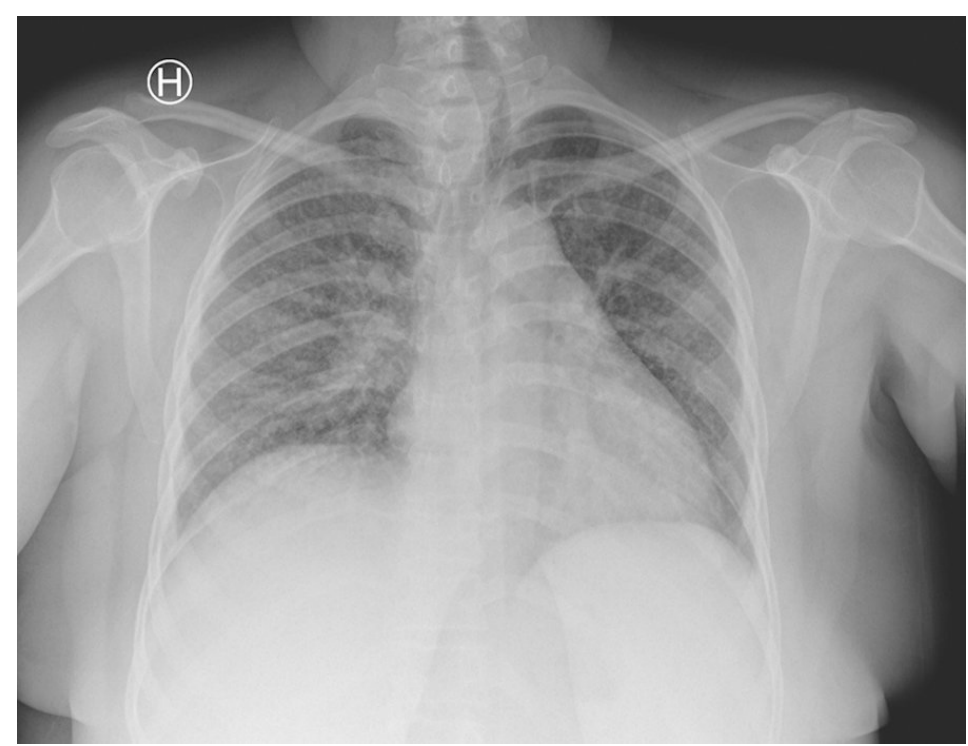

Figur 1 Røntgen thorax (dag 1) viser små nodulcere infiltrater bilateralt

Det ble startet med erytromycin $500 \mathrm{mg} \times 3$ peroralt, med overgang til cefuroksim 1,5 $\mathrm{g} \times 3$ intravenøst etter tre dager med vedvarende feber, deretter skiftet til meropenem $2 \mathrm{~g} \times 3$ intravenøst. Direkte mikroskopi av indusert sputum med $\mathrm{NaCl}$ på forstøver viste ikke syrefaste staver, og materialet ble sendt videre til dyrking på selektivt tuberkulosemedium. Blodkulturer, dyrking og PCR-analyse av ekspektorat med tanke på bakterielle og virale luftveisagenser var alle negative.

Dag 6 ble hodepinen verre, i tillegg så man parese av n. abducens. Pasienten var vedvarende febril, temperaturen lå mellom $38, \mathrm{o}^{\circ} \mathrm{C}$ og $38,5{ }^{\circ} \mathrm{C}$. Ny CT caput med kontrast viste kontrastoppladning ved tentoriet, i cerebellum, i pons samt i høyre oksipitallapp med omkringliggende ødem ( fig 2). MR cerebrum uten kontrast viste lavt signal på T2-vektet sekvens, tilsvarende de kontrastladende lesjonene (fig 3 ). 


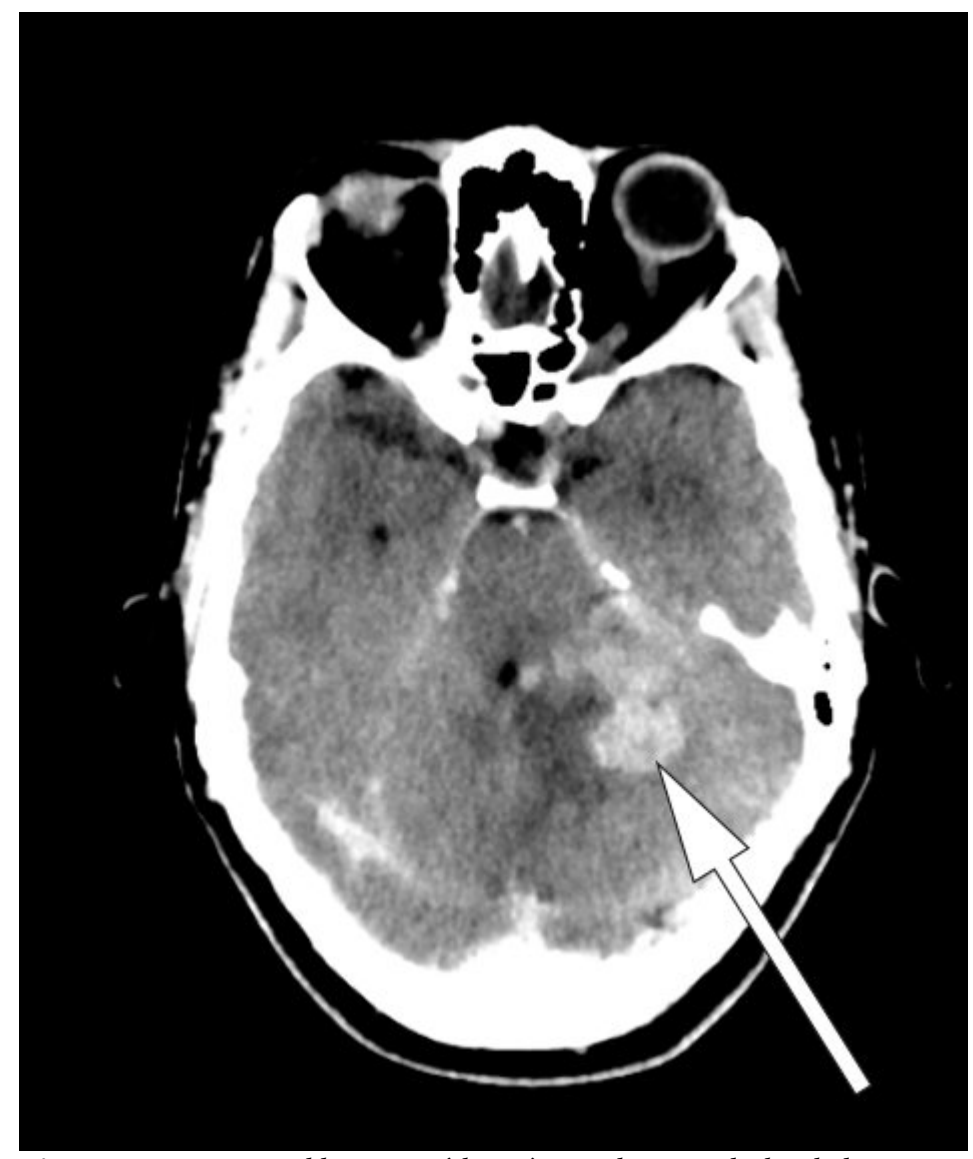

Figur 2 CT caput med kontrast (dag 6) viser kontrastladende lesjoner i venstre lillehjerneshemisfcere med omkringliggende ødem

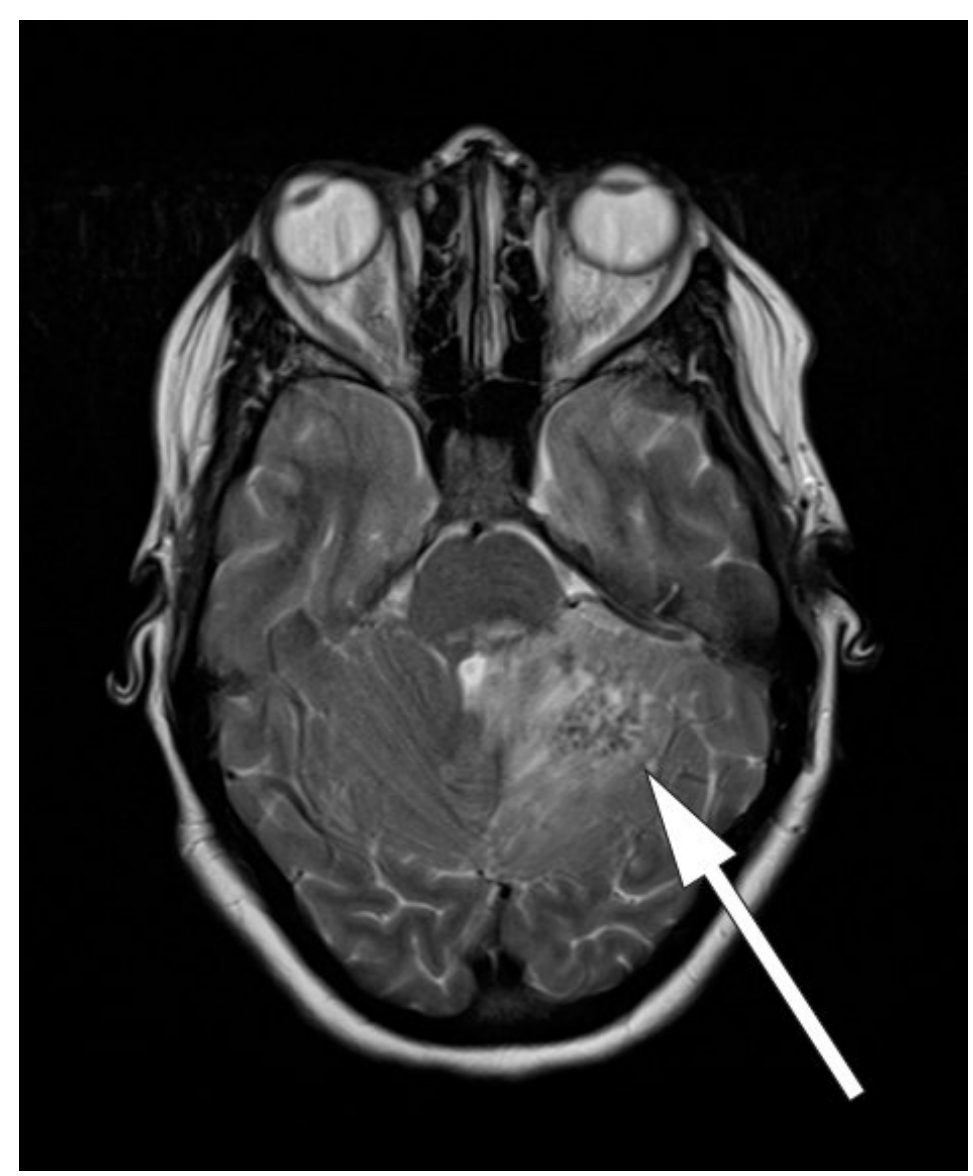

Figur 3 MR cerebrum med T2-vektet sekvens (dag 6) viser ødem med lavt signal sentralt i lesjonene som kan ses ved tuberkulom

Det ble gjort spinalpunksjon med funn av $182 \times 10^{6} / \mathrm{l}$ celler (normalt o-5 $\times 10^{6} / \mathrm{l}$ ), glukose $2,1 \mathrm{mmol} / \mathrm{l}$ (normalt $>2 \mathrm{mmol} / \mathrm{l}$ ) og protein $1,38 \mathrm{~g} / \mathrm{l}$ (normalt o,15-0,50 $\mathrm{g} / \mathrm{l}$ ), funn vel forenlige 
med tuberkuløs meningitt. Den tentative diagnosen var dermed miliær tuberkulose med affeksjon av sentralnervesystemet.

Å diagnostisere tuberkulose i svangerskapet er utfordrende, da mange av sykdomssymptomene kan ligne ordinære svangerskapsplager. Tretthet og anemi er vanlig hos gravide, og den normale vektoppgangen i svangerskapet kan maskere et vekttap. Dette kan føre til forsinket diagnose og behandling. For øvrig er symptomene på lungetuberkulose i svangerskapet i hovedsak lik symptomene hos ikke-gravide: feber, hoste, nattesvette og nedsatt allmenntilstand.

Diagnostisering av tilstanden hos gravide er som hos ikke-gravide basert på klinisk mistanke, sputumdiagnostikk samt røntgen thorax (1). Røntgen thorax utsetter ikke fosteret for målbar risiko og behøver ikke unngås dersom det foreligger indikasjon for undersøkelse.

Dag 8 ble kvinnen overført til infeksjonsmedisinsk avdeling ved et universitetssykehus for tilgang til nevrokirurgisk kompetanse. Hun var da 35 uker og fire dager gravid. Ved innleggelsen var hun våken, men smertepåvirket, febril med en temperatur på 39, ${ }^{\circ} \mathrm{C}$, med blodtrykk 151/81 mm Hg, regelmessig puls på 120/min og med ensidig abduscensparese. Blodprøvene viste $\mathrm{Hb}$ 10,2 g/100 ml (normalverdi ikke-gravide 11,7-15,3 g/100 ml), trombocytter $160 \times 10^{9} \mathrm{E} / \mathrm{l}$ (normalt 145-390 $\times 10^{9} \mathrm{E} / \mathrm{l}$ ), CRP $149 \mathrm{mg} / \mathrm{l}$, ASAT $97 \mathrm{U} / \mathrm{l}$ (normalt 15-35 U/l), LD 309 U/l (normalt 105-205 U/I), ALP 143 U/l (normalt 35-105 U/l), bilirubin 17 umol/l (normalt 5-25 umol/l), prokalsitonin o,3 ug/l (normalt < o,5 ug/l).

En TB-IGRA-test (M. tuberculosis interferon gamma release assay), en immunologisk blodtest basert på antigener spesifikke for M. tuberculosis-komplekset, var positiv. Kvinnen ble luftsmitteisolert.

Det ble på sterk klinisk og radiologisk mistanke umiddelbart startet behandling mot tuberkulose med kombinasjonen isoniazid tablett $300 \mathrm{mg} \times 1$, rifampicin tablett $600 \mathrm{mg} \times 1$, pyrazinamid tablett 2 ooo $\mathrm{mg} \times 1$ og etambutol tablett $1600 \mathrm{mg} \times 1$, alle dosert etter vekt som hos ikke-gravide. Meropenem intravenøst $2 \mathrm{~g} \times 3$ daglig ble videreført. På grunn av cerebral affeksjon fikk hun deksametason intravenøst, initialt $12 \mathrm{mg} \times 4$, deretter $8 \mathrm{mg} \times 3$ daglig.

I fellesmøte med infeksjonsmedisiner, obstetriker, nevrokirurg og neonatolog ble forløsningsindikasjon og tidspunkt diskutert. Maternelt forelå det ødem intrakranialt, med risiko for stigende intrakranialt trykk, herniering og kramper - det var således indikasjon for forløsning. Det ble bestemt snarlig forløsning med keisersnitt på indikasjon miliær tuberkulose med intrakranial affeksjon.

Det er viktig å merke seg at tuberkulin- og TB-IGRA-tester ikke er diagnostiske ved aktiv tuberkulose. Vi fant det også interessant at prokalsitoninnivået i plasma ikke var forhøyet. Ved moderat til sterk mistanke om tuberkulose hos gravide bør det startes behandling før prøvesvar foreligger, da ubehandlet tuberkulose representerer en større fare for mor og barn enn tuberkulostatika.

På bakgrunn av sykdommens art, med granulomdanning, var det ikke grunn til å tro at hjerneødemet ville gå helt tilbake på deksametasonbehandling. Disse aspektene talte for snarlig forløsning, til tross for at dette ville implisere profylaktisk langvarig tuberkulosebehandling av barnet samt isolering fra begge foreldrene de første ukene etter fødselen. Keisersnitt ble valgt fremfor induksjon av vaginal fødsel på grunn av affeksjon av sentralnervesystemet hos kvinnen. Av samme grunn ble inngrepet utført i generell anestesi fremfor i spinalanestesi.

Allerede få timer etter oppstart med deksametason var det tilbakegang av abduscensparesen og betydelig mindre smerter. På bakgrunn av klinisk bedring planla vi elektiv forløsning innen et par dager. Hun ble forløst tre dager etter innkomst (dag 11) med et ukomplisert keisersnitt i narkose i svangerskapsuke 36. Postoperativt fikk hun økte abdominalsmerter med feber 2. dag etter forløsningen, med CRP-stigning til $48 \mathrm{mg} / \mathrm{l}$. CT abdomen viste normale funn. Smertene ga seg og det var deretter et upåfallende 
postpartumforløp.

Barnet, en gutt, veide 2797 g, en normal vekt ut fra svangerskapets lengde, og hadde normal apgarskår på 9-10-10. Det var ingen klinisk mistanke om kongenital tuberkulose. For å hindre postnatal smitte ble han isolert og det ble startet profylaktisk behandling i form av isoniazid og pyridoksin. Han ble behandlet i to måneder, deretter ble det gjort en TB-IGRAtest, som var negativ. Etter en uke ble mor og barn overflyttet til lokalsykehuset. Etter to ukers tuberkulosebehandling kunne kvinnen ha kontakt med barnet og amme ham. Histologisk undersøkelse av placenta viste tegn til maternell malperfusjon samt abscess i decidua, men det ble ikke påvist syrefaste staver i denne. Dyrking av indusert sputum fra kvinnen ga oppvekst av tuberkulosebakterier etter to uker. Ved resistensbestemmelse ved Folkehelseinstituttet ble det ikke angitt resistens mot ordinære tuberkulosemedikamenter. Kvinnen ble behandlet med fire forskjellige tuberkulosemidler i to måneder, deretter gikk man over til kun rifampicin og isoniazid, med planlagt total behandlingstid på 9-12 måneder.

Da kvinnen var tilbake på lokalsykehuset, ble det påvist noe styringsproblemer i høyre underekstremitet, for øvrig var det ingen nevrologiske utfall. Ved kontroll etter fire måneders behandling hadde hun fortsatt lette styringsvansker i høyre underekstremitet, ellers var hun symptomfri. Barnet er friskt, med normal utvikling.

Medfødt tuberkulose er en sjelden komplikasjon til hematogen smitte in utero fra mor til barn og er knyttet til høy perinatal dødelighet (2). Median alder for debut er rundt 24 dager, og symptomene er uspesifikke. Imidlertid er risikoen for postnatal smitte fra omsorgsperson betydelig høyere. Amming utgjør allikevel ikke noen risiko dersom moren har vært tuberkulosebehandlet i minst to uker. Barnet bør fă tilskudd av pyridoksin (vitamin $\mathrm{B}_{6}$ ), da overgang av isoniazid i morsmelken gir risiko for pyridoksinmangel.

I vårt tilfelle var de initiale prøvene fra barnet alle negative for tuberkulose, således var det ikke holdepunkter for intrauterin smitte. Abscess i decidualaget i morkaken kan dog være en uspesifikk reaksjon på en placentær tuberkuloseinfeksjon.

Når det gjelder smitteoppsporing, ble ansvarlig kommuneoverlege koblet inn. Vedkommende hadde den videre kontakten med Folkehelseinstituttet, med tanke på sammenligning av bakteriestammer med andre tilfeller av aktiv tuberkulose.

\section{Diskusjon}

Tuberkulose i svangerskap i høyinntektsland er en sjelden, men alvorlig tilstand for mor og barn. Det foreligger en doblet risiko for maternelle svangerskapskomplikasjoner, og det er $\emptyset \mathrm{kt}$ risiko for spontanabort, for tidlig fødsel, veksthemming hos barnet og $\mathrm{d} ø \mathrm{~d} \mathrm{i}$ nyfødtperioden.

Forekomsten hos gravide i høyinntekstland skiller seg ikke vesentlig fra forekomsten hos ikke-gravide. I Norge er det etter 2010 rapportert ett mødredødsfall på grunn av tuberkulose. Dette var hos en utenlandsfødt kvinne som fikk påvist tuberkuløs meningitt sent i svangerskapet og som døde av sykdommen fem uker etter forløsningen (personlig meddelelse L. Ellingsen, Den norske auditgruppe for mødredødsfall). I Sverige er det rapportert to tilfeller av mødredødsfall grunnet sykdommen i perioden 1988-2010, begge gjaldt utenlandsfødte kvinner (3).

I Storbritannia har det vært en økning i tuberkuloserelaterte dødsfall i svangerskapet (4). I en 12-månedersstudie var det der 32 tilfeller av tuberkulose hos gravide, tilsvarende en insidens på 4,2 per 100 ooo svangerskap (5). Dette ble vurdert som et minimumsestimat. Den britiske studien viste at tuberkulose i svangerskapet nærmest utelukkende forekom hos utenlandsfødte kvinner med opprinnelse fra høyendemiske kontinenter som Afrika (høyest hos kvinner født i Somalia) og Asia (høyest hos kvinner født i India og Pakistan). Median tid fra innvandring til Storbritannia på diagnosetidspunktet var 4,5 år (spredning 2 md.-11 år). Av de 32 tilfellene i Storbritannia var 50 \% ekstrapulmonale og $50 \%$ pulmonale. Det var ett dødsfall hos en kvinne med tuberkuløs meningitt, hun døde innen to uker etter 
at diagnosen var stilt.

I USA er insidensen av tuberkulose i svangerskap høyere (26,6 per 100 ooo fødsler) og man ser en tilsvarende tendens - økende insidens og økt antall maternelle dødsfall grunnet sykdommen (6).

Var vårt tilfelle et resultat av nysmitte eller var det forårsaket av reaktivering av latent sykdom? Kvinnen hadde bodd over ti år i Norge og hadde ikke kjent latent tuberkulose. Hun kan ha blitt smittet under et feriebesøk i hjemlandet noen år tidligere.

Smitteoppsporing her i landet har ikke vist kjente kontakter med sykdommen. Således er det mest sannsynlig at hun ble smittet under besøket i hjemlandet og fikk en reaktivering under det aktuelle svangerskapet.

En tredel av verdens befolkning har latent tuberkulose, en tilstand der mikrobene befinner seg i en ikke-replikerende eller langsomt replikerende fase med endret metabolisme som beskyttelse mot et fiendtlig ytre miljø. Latent tuberkulose kan vare hele livet ut, og det er en $10 \%$ livstidsrisiko for reaktivering med utvikling av aktiv tuberkulose, som oftest innen to år fra primærinfeksjonen. De som har diabetes, er hivpositive eller av noen annen grunn er immunsupprimert, har økt risiko for reaktivering. TB-IGRA-testen er nyttig for å vurdere om latens foreligger.

Det er ikke sikkert påvist at graviditet gir økt risiko for reaktivering eller påvirker sykdomsutviklingen av aktiv tuberkulose $(6,7)$. Svangerskap er allikevel en tilstand der immunresponsen endres. Det er vist at reaktivering av tuberkulose er vanligere post partum, og det er stilt spørsmål ved om dette er infeksjoner som starter under svangerskapet, men som altså først diagnostiseres etter fødselen (8).

Det foreligger ikke spesifikke norske retningslinjer for latent tuberkulose i svangerskapet. Folkehelseinstituttet anbefaler ikke rutinemessig testing for dette hos gravide, med mindre kvinnen inngår i grupper som har plikt til tuberkuloseundersøkelse eller det foreligger betydelig immunsuppresjon, som ved hivinfeksjon (1).

Det finnes ingen gullstandard for å diagnostisere latent tuberkulose, men diagnosen kan sannsynliggjøres på bakgrunn av eksponering, opprinnelsesland, resultat av TB-IGRA-test eller tuberkulintest (Mantoux) og røntgen thorax. Dersom latent tuberkulose påvises hos en gravid og hun fyller behandlingskriteriene, anbefaler Folkehelseinstituttet at man venter med behandlingen inntil 2-3 måneder etter fødselen. Amming er ingen kontraindikasjon mot behandling (1).

Vår kasuistikk viser at det å stille diagnosen tuberkulose kan være særlig utfordrende hos gravide. De har ofte et bredt spekter av plager. Noen av kvinnene kan imidlertid enkelte ganger være alvorlig syke. Symptomer på tuberkulose kan ligne vanlige svangerskapsplager, noe som kan forsinke diagnosen. Tilbakeholdenhet med adekvate radiologiske undersøkelser grunnet frykt for fosterskade kan også forsinke korrekt diagnose og oppstart av behandling.

Hos vår pasient ble diagnosen stilt etter rimelig tid, men gitt hennes opprinnelsesland og funn av bilaterale lungefortetninger, uten effekt av standard antibiotikabehandling, kunne behandlingen vært startet før. Særlig ved tuberkulose med affeksjon av sentralnervesystemet er rask behandling essensielt, og kvinnens helse bør gå foran forlengelse av svangerskapet når fosteret er levedyktig.

Et tverrfaglig behandlingsteam er viktig for optimal behandling og ivaretaking av to pasienter - mor og foster. Det er viktig at man i svangerskapsomsorgen har lav terskel for å iverksette undersøkelse for aktiv tuberkulosesykdom i graviditeten hos kvinner med opprinnelse i et høyendemisk land og et initialt uklart sykdomsbilde. 
2. Sobhy S, Babiker Z, Zamora J et al. Maternal and perinatal mortality and morbidity associated with tuberculosis during pregnancy and the postpartum period: a systematic review and meta-analysis. BJOG 2017; 124: 727-33. [PubMed][CrossRef]

3. Esscher A, Binder-Finnema P, Bødker B et al. Suboptimal care and maternal mortality among foreign-born women in Sweden: maternal death audit with application of the 'migration three delays' model. BMC Pregnancy Childbirth 2014; 14: 141. [PubMed][CrossRef]

4. Lewis G, red. The Confidential Enquiry into Maternal and Child health (CEMACH). Saving Mothers Lives: Reviewing Maternal Deaths to Make Childhood Safer - 2003-2005. London: CEMACH, 2007. http://www.publichealth.hscni.net/sites/default/files/Saving\%2oMothers\%27\%20Lives\%202003-05\%20.p df(6.12.2017).

5. Knight M, Kurinczuk JJ, Nelson-Piercy C et al. Tuberculosis in pregnancy in the UK. BJOG 2009; 116: 584 - 8. [PubMed][CrossRef]

6. El-Messidi A, Czuzoj-Shulman N, Spence AR et al. Medical and obstetric outcomes among pregnant women with tuberculosis: a population-based study of 7.8 million births. Am J Obstet Gynecol 2016; 215: 797.e1 - 6. [PubMed][CrossRef]

7. Mathad JS, Gupta A. Tuberculosis in pregnant and postpartum women: epidemiology, management, and research gaps. Clin Infect Dis 2012; 55: 1532 - 49. [PubMed][CrossRef]

8. Zenner D, Kruijshaar ME, Andrews N et al. Risk of tuberculosis in pregnancy: a national, primary care-based cohort and self-controlled case series study. Am J Respir Crit Care Med 2012; 185: 779 - 84. [PubMed][CrossRef]

Publisert: 19. februar 2018. Tidsskr Nor Legeforen. DOI: 10.4045/tidsskr.17.0383

Mottatt 26.4.2017, første revisjon innsendt 28.10.2017, godkjent 6.12.2017.

(C) Tidsskrift for Den norske legeforening 2020. Lastet ned fra tidsskriftet.no 